\title{
Cyclic Nitriles: Diastereoselective Alkylations
}

Fraser F. Fleming, * Subrahmanyam Gudipati, Zhiyu Zhang, Wang Liu, and Omar W. Steward. Department of Chemistry and Biochemistry, Duquesne University, Pittsburgh, Pennsylvania 15282-1530.

flemingf@duq.edu

\begin{tabular}{|l|c|c|c|c|c|}
\hline Compound & Reference & Procedure & ${ }^{1}$ H NMR & ${ }^{\mathbf{1 3}}$ C NMR & X-ray $^{\mathbf{1}}$ \\
\hline 14a & 2 & $\mathrm{~S} 1, \mathrm{~S} 4$ & $\mathrm{~S} 7$ & $\mathrm{~S} 8$ & \\
$\mathbf{1 4 b}$ & & $\mathrm{S} 2$ & $\mathrm{~S} 9$ & $\mathrm{~S} 10$ & \\
$\mathbf{1 4 c}$ & 3 & $\mathrm{~S} 3, \mathrm{~S} 4, \mathrm{~S} 6$ & $\mathrm{~S} 11$ & $\mathrm{~S} 12$ & \\
$\mathbf{1 4 d}$ & & $\mathrm{S} 6$ & $\mathrm{~S} 13$ & $\mathrm{~S} 14$ & \\
$\mathbf{1 5 d}$ & & $\mathrm{S} 6$ & $\mathrm{~S} 15$ & $\mathrm{~S} 16$ & \\
i (CCDC\# 259789) & & $\mathrm{S} 6$ & $\mathrm{~S} 17$ & $\mathrm{~S} 18$ & $\mathrm{~S} 19$ \\
$\mathbf{1 9 a}$ & & $\mathrm{S} 3$ & $\mathrm{~S} 20$ & $\mathrm{~S} 21$ & \\
$\mathbf{1 9 b}$ & & $\mathrm{S} 3$ & $\mathrm{~S} 22$ & $\mathrm{~S} 23$ & \\
References & $\mathrm{S} 24$ & & & & \\
\hline
\end{tabular}

Experimental $^{4}$

General deprotonation-alkylation procedure: A THF solution (1M) of lithium diethylamide (prepared by addition of a hexanes solution of $\mathrm{BuLi}, 1.27$ equivalents, to diethylamine, 1.33 equivalents) was added to a room temperature THF solution of $\mathbf{1 3}$ (1.0 equiv). After 5 min neat alkyl halide ( 2 equiv) was added followed, after 15 min, by saturated, aqueous $\mathrm{NH}_{4} \mathrm{Cl}$. The crude product was extracted with EtOAc, dried (MgSO4), concentrated, and purified by radial chromatography to afford analytically pure material.

4-tert-Butyl-1-methylcyclohexanecarbonitrile (14a and 15a): The general deprotonationalkylation procedure was employed with $\mathbf{1 3}^{5}(18 \mathrm{mg}, 0.11 \mathrm{mmol}), \mathrm{LiNEt}_{2}$, and methyl iodide to afford $17 \mathrm{mg}(86 \%)$ of $\mathbf{1 4 a}$ and $\mathbf{1 5 a}$, in a $2.8: 1$ ratio, $^{6}$ identical to material previously isolated and analyzed by $60 \mathrm{MHz}{ }^{1} \mathrm{H} \mathrm{NMR}^{2}$ An analytically pure sample of 14a gave the following spectral 
data: IR (film) $2230 \mathrm{~cm}^{-1} ;{ }^{1} \mathrm{H}$ NMR $\left(300 \mathrm{MHz}, \mathrm{CDCl}_{3}\right) \delta 0.84(\mathrm{~s}, 9 \mathrm{H}), 0.89-1.03(\mathrm{~m}, 1 \mathrm{H}), 1.30$ (s, 3H), 1.16-1.42 (m, 4H), $1.74(\mathrm{~d}, J=11.8 \mathrm{~Hz}, 2 \mathrm{H}), 1.99(\mathrm{~d}, J=13.2 \mathrm{~Hz}, 2 \mathrm{H}) ;{ }^{13} \mathrm{C}$ NMR $(75$ $\left.\mathrm{MHz}, \mathrm{CDCl}_{3}\right) \delta 24.4,27.3,27.4,32.3,34.5,37.8,47.2,124.4$; HRMS(EI) calcd for $\left(\mathrm{M}^{+}\right)$, $\mathrm{C}_{12} \mathrm{H}_{21} \mathrm{~N}^{+} 179.1669$, found 179.1679 . Repeating the general procedure with a DME solution of $\mathbf{1 3}^{5}(17 \mathrm{mg}, 0.10 \mathrm{mmol}), \mathrm{LiNEt}_{2}$ and methyl iodide at $-60{ }^{\circ} \mathrm{C}$ afforded $16 \mathrm{mg}(86 \%)$ of $\mathbf{1 4 a}$ and 15a in a 7.7:1 ratio. ${ }^{6}$ Repeating the general procedure with $13^{5}$ (23 $\left.\mathrm{mg}, 0.14 \mathrm{mmol}\right), \mathrm{LiNEt}_{2}$ and methyl iodide at $-78{ }^{\circ} \mathrm{C}$ afforded $21 \mathrm{mg}(85 \%)$ of $\mathbf{1 4 a}$ and $15 \mathrm{a}$ in a $7.4: 1$ ratio. ${ }^{6}$ Addition of a THF solution (1M) of $\mathrm{LiNEt}_{2}$ to a $66^{\circ} \mathrm{C}$ THF solution of $\mathbf{1 3}^{5}(25 \mathrm{mg}, 0.15 \mathrm{mmol})$, was followed, after $30 \mathrm{~s}$ by methyl iodide. After a further $5 \mathrm{~min}$ the solution was cooled, saturated, aqueous $\mathrm{NH}_{4} \mathrm{Cl}$ was added and the crude product was then extracted with EtOAc, dried (MgSO4), concentrated, and purified by radial chromatography to afford and methyl iodide at $66{ }^{\circ} \mathrm{C}$ afforded $24.4 \mathrm{mg}(90 \%)$ of $\mathbf{1 4 a}$ and 15a in a 1.9:1 ratio. $^{6}$ Repeating the general procedure with $\mathbf{1 3}^{5}$ (20 mg, $0.12 \mathrm{mmol}$ ), KHMDS (0.19 mmol), and methyl iodide, but in toluene rather than THF, at $22{ }^{\circ} \mathrm{C}$ afforded $18 \mathrm{mg}(84 \%)$ of $\mathbf{1 4 a}$ and 15a in a $1.6: 1$ ratio. ${ }^{6}$ Addition of a toluene solution (1M) of KHMDS $(0.19 \mathrm{mmol})$ to an $80^{\circ} \mathrm{C}$ toluene solution of $13^{5}(26 \mathrm{mg}, 0.16 \mathrm{mmol})$ was followed, after $30 \mathrm{~s}$ by methyl iodide. After a further $5 \mathrm{~min}$ the solution was cooled, saturated, aqueous $\mathrm{NH}_{4} \mathrm{Cl}$ was added and the crude product was then extracted with EtOAc, dried (MgSO4), concentrated, and purified by radial chromatography to afford $20 \mathrm{mg}$ (71\%) of 14a and 15a in a $1: 1$ ratio. $^{6}$

4-tert-Butyl-1-propyl-cyclohexanecarbonitrile (14b): The general deprotonation-alkylation procedure was employed with a THF solution of $\mathbf{1 3}^{5}\left(17 \mathrm{mg}, 0.10 \mathrm{mmol}^{2}, \mathrm{LiNEt}_{2}\right.$ and n-propyl bromide at $-78{ }^{\circ} \mathrm{C}$ to afford $13 \mathrm{mg}(71 \%)$ of $\mathbf{1 4 b}$ as an oil: IR (film) $2230 \mathrm{~cm}^{-1} ;{ }^{1} \mathrm{H}$ NMR (300 $\left.\mathrm{MHz}, \mathrm{CDCl}_{3}\right) \delta 0.87(\mathrm{~s}, 9 \mathrm{H}), 0.93-1.61(\mathrm{~m}, 12 \mathrm{H}), 1.78(\mathrm{br} \mathrm{d}, J=13.2,2 \mathrm{H}), 2.05$ (br d, $J=13.2$ 
$\mathrm{Hz}, 2 \mathrm{H}) ;{ }^{13} \mathrm{C} \mathrm{NMR}\left(75 \mathrm{MHz}, \mathrm{CDCl}_{3}\right) \delta 14.2,17.9,24.2,27.4,32.3,36.2,39.0,42.9,47.7,123.7$; MS m/z $208(\mathrm{M}+\mathrm{H})$.

1-Allyl-4-tert-butyl-cyclohexanecarbonitrile (14c) and (15c): The general deprotonationalkylation procedure was employed with a THF solution of $\mathbf{1 3}^{5}$ (20 $\left.\mathrm{mg}, 0.12 \mathrm{mmol}\right), \mathrm{LiNEt}_{2}$ and allyl bromide at $-78{ }^{\circ} \mathrm{C}$ to afford $18.4 \mathrm{mg}(74 \%)$ of $14 \mathrm{c}$ and $15 \mathrm{c}$ in a $7.9: 1$ ratio $^{6}$ identical to materials previously isolated and analyzed by $60 \mathrm{MHz}{ }^{1} \mathrm{H}$ NMR. ${ }^{3}$ An analytically pure sample of 14c gave the following spectral data: IR (film) 3080, 2231, $1642 \mathrm{~cm}^{-1} ;{ }^{1} \mathrm{H}$ NMR (500 MHz, $\left.\mathrm{CDCl}_{3}\right) \delta 0.88(\mathrm{~s}, 9 \mathrm{H}), 0.92-1.00(\mathrm{~m}, 1 \mathrm{H}), 1.19-1.45(\mathrm{~m}, 4 \mathrm{H}), 1.80(\mathrm{br} \mathrm{d}, J=11.8 \mathrm{~Hz}, 2 \mathrm{H}), 2.04$ (br d, J = 11.8 Hz, 2H), $2.28(\mathrm{~d}, J=7.4 \mathrm{~Hz}, 2 \mathrm{H}), 5.15-5.23(\mathrm{~m}, 2 \mathrm{H}), 5.83-5.97(\mathrm{~m}, 1 \mathrm{H}) ;{ }^{13} \mathrm{C}$ $\operatorname{NMR}\left(75 \mathrm{MHz}, \mathrm{CDCl}_{3}\right) \delta$ 21.0, 24.1, 27.4, 32.3, 33.7, 35.8, 38.9, 44.7, 47.5, 119.6, 123.2, 132.0; HRMS (EI) for $\mathrm{C}_{14} \mathrm{H}_{23} \mathrm{ClN}$ : calcd 205.1825, found 205.1842.

1-Bromo-4-tert-butylcyclohexanecarbonitrile (19): Neat bromine (1.28 g, $8 \mathrm{mmol})$ and nitrile $\mathbf{1 3}^{5}$ (1.22 g, $\left.7.4 \mathrm{mmol}\right)$, were sequentially added to ice-cooled $\operatorname{PBr}_{3}(2.16 \mathrm{~g}, 8 \mathrm{mmol})$. After the addition, the ice bath was removed and the reaction was heated at $60{ }^{\circ} \mathrm{C}$. After $5 \mathrm{~h}$ the mixture was poured onto ice, extracted with ether, and then the crude extracts were washed with $\mathrm{NaHCO}_{3}$, and water, and then dried $\left(\mathrm{MgSO}_{4}\right)$. Concentration and purification of the crude product by radial chromatography (1: 48 to $1: 24$ EtOAc/hexanes), afforded $1.32 \mathrm{~g}$ of 19 (yield: 73\%) as an oil (mixture about 1:1). For one diastereomer (19a): IR (film) $2239 \mathrm{~cm}^{-1} ;{ }^{1} \mathrm{H}$ NMR $\left(300 \mathrm{MHz}, \mathrm{CDCl}_{3}\right) \delta 0.89(\mathrm{~s}, 9 \mathrm{H}), 1.04-1.11(\mathrm{~m}, 1 \mathrm{H}), 1.45-1.55(\mathrm{~m}, 2 \mathrm{H}), 1.74-1.79(\mathrm{~m}, 2 \mathrm{H})$, $1.90-2.01(\mathrm{~m}, 2 \mathrm{H}), 2.37-2.42(\mathrm{~m}, 2 \mathrm{H}) ;{ }^{13} \mathrm{C} \mathrm{NMR}\left(75 \mathrm{MHz}, \mathrm{CDCl}_{3}\right) \delta$ 21.7, 27.1, 32.3, 39.5, 46.2, 120.8; MS m/z 244/246 (M+H). For the second diastereomer (19b): IR (film) $2234 \mathrm{~cm}^{-1}$; ${ }^{1} \mathrm{H}$ NMR $\delta 0.87(\mathrm{~s}, 9 \mathrm{H}), 1.05-1.16(\mathrm{~m}, 1 \mathrm{H}), 1.37-1.51(\mathrm{~m}, 2 \mathrm{H}), 1.80-1.84(\mathrm{~m}, 2 \mathrm{H}), 2.00-2.10$ 
(m, 2H), $2.56-2.60(\mathrm{~m}, 2 \mathrm{H}) ;{ }^{13} \mathrm{C}$ NMR 26.4, 27.2, 32.1, 42.0, 45.1, 46.0, 119.2. HRMS(EI)

calcd for $\left(\mathrm{M}^{+}\right), \mathrm{C}_{11} \mathrm{H}_{18} \mathrm{BrN}^{+}$243.0617, found 243.0671.

General bromine-magnesium exchange-alkylation procedure: A THF solution of $i-\mathrm{PrMgBr}$ (1.05 equiv) was added to a $-78{ }^{\circ} \mathrm{C}$, THF $(1 \mathrm{mmol})$ solution of $\mathbf{1 9}$ (1.0 equiv) and the electrophile (1.05 equiv). After $2 \mathrm{~h}$ saturated, aqueous $\mathrm{NH}_{4} \mathrm{Cl}$ solution was added, the crude product extracted with EtOAc, dried, concentrated and purified by radial chromatography to afford analytically pure material by IR, HRMS, and ${ }^{1} \mathrm{H}$ and ${ }^{13} \mathrm{C}$ NMR.

4-tert-butyl-1-methylcyclohexanecarbonitrile (14a): The general bromine-magnesium procedure was employed with $19(150 \mathrm{mg}, 0.61 \mathrm{mmol})$ and methyl iodide (173 $\mathrm{mg}, 1.22 \mathrm{mmol})$ to afford, after purification by radial chromatography (stepped gradient 2:49, 1:19 EtOAc/hexanes), 14a $66 \mathrm{mg}(61 \%)$. Repeating the standard procedure at $0{ }^{\circ} \mathrm{C}$ with $19(80 \mathrm{mg}$, $0.33 \mathrm{mmol})$ and $i-\operatorname{PrMgBr}(0.34 \mathrm{mmol})$ afforded $44 \mathrm{mg}(75 \%)$ of 14a spectrally identical to material previously isolated. Repeating the standard procedure at room temperature with $\mathbf{1 9}$ (280 $\mathrm{mg}, 1.15 \mathrm{mmol})$ and $i-\operatorname{PrMgBr}(1.27 \mathrm{mmol})$ afforded $180 \mathrm{mg}(87 \%)$ of 14a spectrally identical to material previously isolated. Repeating the standard procedure with $19(100 \mathrm{mg}, 0.41 \mathrm{mmol})$ and BuLi ( $0.45 \mathrm{mmol})$ afforded $31 \mathrm{mg}(43 \%)$ of $\mathbf{1 4 a}$ and $10 \mathrm{mg}(13 \%)$ of $\mathbf{1 5 a}$ spectrally identical to materials previously isolated.

cis-1-Allyl-4-tert-butyl-cyclohexanecarbonitrile (14c): The general bromine-magnesium exchange-alkylation was employed with 19 (100 mg, $0.41 \mathrm{mmol})$ and allyl bromide (71.4 mg, $0.59 \mathrm{mmol}$ ) to afford, after purification by radical chromatography (1:50 EtOAc/Hexanes), 64.7 $\operatorname{mg}(77 \%)$ of $14 c$ and $15 c$ in a $22: 1$ ratio. 
Methyl 4-tert-butyl-1-cyanocyclohexanecarboxylate (14d) and (15d). The general brominemagnesium procedure was employed with one diastereomer of 19 (156 mg, $0.64 \mathrm{mmol}), i$ $\operatorname{PrMgBr}(0.7 \mathrm{mmol})$ and methyl cyanoformate $(1.28 \mathrm{mmol})$ to afford, after purification by radial chromatography (stepped gradient 1:48,1:24 EtOAc/hexanes), $82 \mathrm{mg}$ (57\%) of 14d and $7 \mathrm{mg}$ (5\%) of 15d: Repeating the standard procedure with the other diastereomer of 19 (150 mg, 0.62 $\mathrm{mmol}), i-\mathrm{PrMgBr}(0.8 \mathrm{mmol})$ and methyl cyanoformate $(1.24 \mathrm{mmol})$ afforded, after purification by radial chromatography (stepped gradient 1:48,1:24 EtOAc/hexanes), $94 \mathrm{mg}(69 \%)$ of 14d and $5 \mathrm{mg}(4 \%)$ of $\mathbf{1 5 d}$ and $15 \mathrm{mg}$ of recovered 19. For 14d IR (film) $2240 \mathrm{~cm}^{-1} ;{ }^{1} \mathrm{H} \mathrm{NMR}(300 \mathrm{MHz}$, $\left.\mathrm{CDCl}_{3}\right) \delta 0.82(\mathrm{~s}, 9 \mathrm{H}), 0.94-1.20(\mathrm{~m}, 3 \mathrm{H}), 1.50-1.82(\mathrm{~m}, 4 \mathrm{H}), 2.54-2.58(\mathrm{~m}, 2 \mathrm{H}), 3.81(\mathrm{~s}, 3 \mathrm{H})$ ${ }^{13} \mathrm{C} \mathrm{NMR}\left(75 \mathrm{MHz}, \mathrm{CDCl}_{3}\right) \delta 23.1,27.3,32.3,33.5,41.8,46.5,53.3,120.7,168.1$; HRMS(ESI) calcd for $\left(\mathrm{M}^{+}\right), \mathrm{C}_{13} \mathrm{H}_{21} \mathrm{NO}_{2} \mathrm{Na}^{+} 246.1464$, found 246.1476. For 15d IR (film) $2241 \mathrm{~cm}^{-1}$; ${ }^{1} \mathrm{H}$ NMR $\left(300 \mathrm{MHz}, \mathrm{CDCl}_{3}\right) \delta 0.88(\mathrm{~s}, 9 \mathrm{H}), 1.01-1.05(\mathrm{~m}, 1 \mathrm{H}), 1.36-1.55(\mathrm{~m}, 3 \mathrm{H}), 1.74-1.88(\mathrm{~m}, 3 \mathrm{H})$, 2.18-2.22 (m, 2H), $3.81(\mathrm{~s}, 3 \mathrm{H}) ;{ }^{13} \mathrm{C}$ NMR (75 $\left.\mathrm{MHz}, \mathrm{CDCl}_{3}\right) \delta 23.3,27.3,32.3,33.3,45.4,46.6$, 53.3, 118.9, 170.0; HRMS(ESI) calcd for $\left(\mathrm{M}^{+}\right), \mathrm{C}_{13} \mathrm{H}_{21} \mathrm{NO}_{2} \mathrm{Na}^{+}$246.1464, found 246.1467.

General Bromine-Copper exchange-alkylation Procedure: A THF solution of 19 (1.0 equiv) was added to a $0{ }^{\circ} \mathrm{C}$, ether solution of $\mathrm{Me}_{2} \mathrm{CuLi}$ [generated by adding methyllithium (2.2 equiv) to copper iodide (1.2 equiv)]. After $1 \mathrm{~h}$ the mixture was cooled to $-78{ }^{\circ} \mathrm{C}$ and the electrophile $(1.3$ equiv) was added neat. After a further $1 \mathrm{~h}$ at $-78{ }^{\circ} \mathrm{C}$, saturated, aqueous $\mathrm{NH}_{4} \mathrm{Cl}$ solution was then added. The mixture was stirred vigorously with exposure to air for $30 \mathrm{~min}$, the crude product was extracted with ether, dried $\left(\mathrm{MgSO}_{4}\right)$, concentrated and purified by radial chromatography to afford analytically pure material. 
cis-1-Allyl-4-tert-butyl-cyclohexanecarbonitrile (14c): The general bromine-copper exchangealkylation procedure was employed with $19(72.9 \mathrm{mg}, 0.30 \mathrm{mmol})$ and allyl bromide $(47.2 \mathrm{mg}$, $0.39 \mathrm{mmol})$ to afford, after purification by radical chromatography (1:50 EtOAc/hexanes), $\mathbf{1 4 c}$ $56.6 \mathrm{mg}(92 \%)$ as an oil.

Methyl 4-tert-butyl-1-cyanocyclohexanecarboxylate (14d and 15d). The general brominecopper exchange-alkylataion procedure was employed with $19(72.9 \mathrm{mg}, 0.30 \mathrm{mmol})$ and methyl cyanoformate $(33.2 \mathrm{mg}, 0.39 \mathrm{mmol})$ to afford, $46.1 \mathrm{mg}(68.9 \%)$ of $\mathbf{1 4 d}$ and $2.71 \mathrm{mg}(4.1 \%)$ of $15 d$.

trans-4-tert-Butyl-1-(hydroxymethyl)cyclohexanecarbonitrile (i): Solid $\mathrm{LiBH}_{4}(65.1 \mathrm{mg}, 3$ mmol) was added to a room temperature, THF solution $(8 \mathrm{~mL})$ of $\mathbf{1 4 d}(66.9 \mathrm{mg}, 0.3 \mathrm{mmol})$. After $30 \mathrm{~h}$ saturated aqueous $\mathrm{NaHCO}_{3}(1 \mathrm{~mL})$ and brine $(1 \mathrm{~mL})$ were added and the resulting mixture stirred for $15 \mathrm{~min}$. The organic phase was separated, the aqueous phase extracted with $\mathrm{Et}_{2} \mathrm{O}(3 \times$ $3 \mathrm{~mL}$ ), and the combined organic phases were then dried $\left(\mathrm{MgSO}_{4}\right)$, filtered, and concentrated. The residue was purified by radial chromatography (1:4 EtOAc/hexanes) to afford $48.0 \mathrm{mg}$ $(82 \%)$ of $\mathbf{i}$ as a colorless, crystalline solid (m.p. $72-74^{\circ} \mathrm{C}$ ) whose structure was assigned by $\mathrm{x}$-ray crystallography: IR (film) 3461, $2247 \mathrm{~cm}^{-1} ;{ }^{1} \mathrm{H}$ NMR $\left(300 \mathrm{MHz}, \mathrm{CDCl}_{3}\right) \delta$ 0.81-0.98 (m, 1H), $0.88(\mathrm{~s}, 9 \mathrm{H}), 1.16-1.45(\mathrm{~m}, 4 \mathrm{H}), 1.81-1.86(\mathrm{~m}, 2 \mathrm{H}), 1.98(\mathrm{br} \mathrm{s}, 1 \mathrm{H}), 2.07-2.11(\mathrm{~m}, 2 \mathrm{H}), 3.60(\mathrm{~s}$, $2 \mathrm{H}) ;{ }^{13} \mathrm{C}$ NMR $\left(75 \mathrm{MHz}, \mathrm{CDCl}_{3}\right) \delta 23.7,27.4,32.4,42.2,47.6,69.1,122.7$; HRMS(ESI) calcd for $\left(\mathrm{M}^{+\mathrm{Na}^{+}}\right), \mathrm{C}_{12} \mathrm{H}_{21} \mathrm{NONa}^{+} 218.1515$, found 218.1507; Anal. calcd. for $\mathrm{C}_{12} \mathrm{H}_{21} \mathrm{NO}$ : C, 73.8; $\mathrm{H}$, $10.8 ; \mathrm{N}, 7.2 ; \mathrm{O}, 8.2$. Found $\mathrm{C}, 73.8 ; \mathrm{H}, 10.6 ; \mathrm{N}, 6.9 ; \mathrm{O}, 8.1$. 


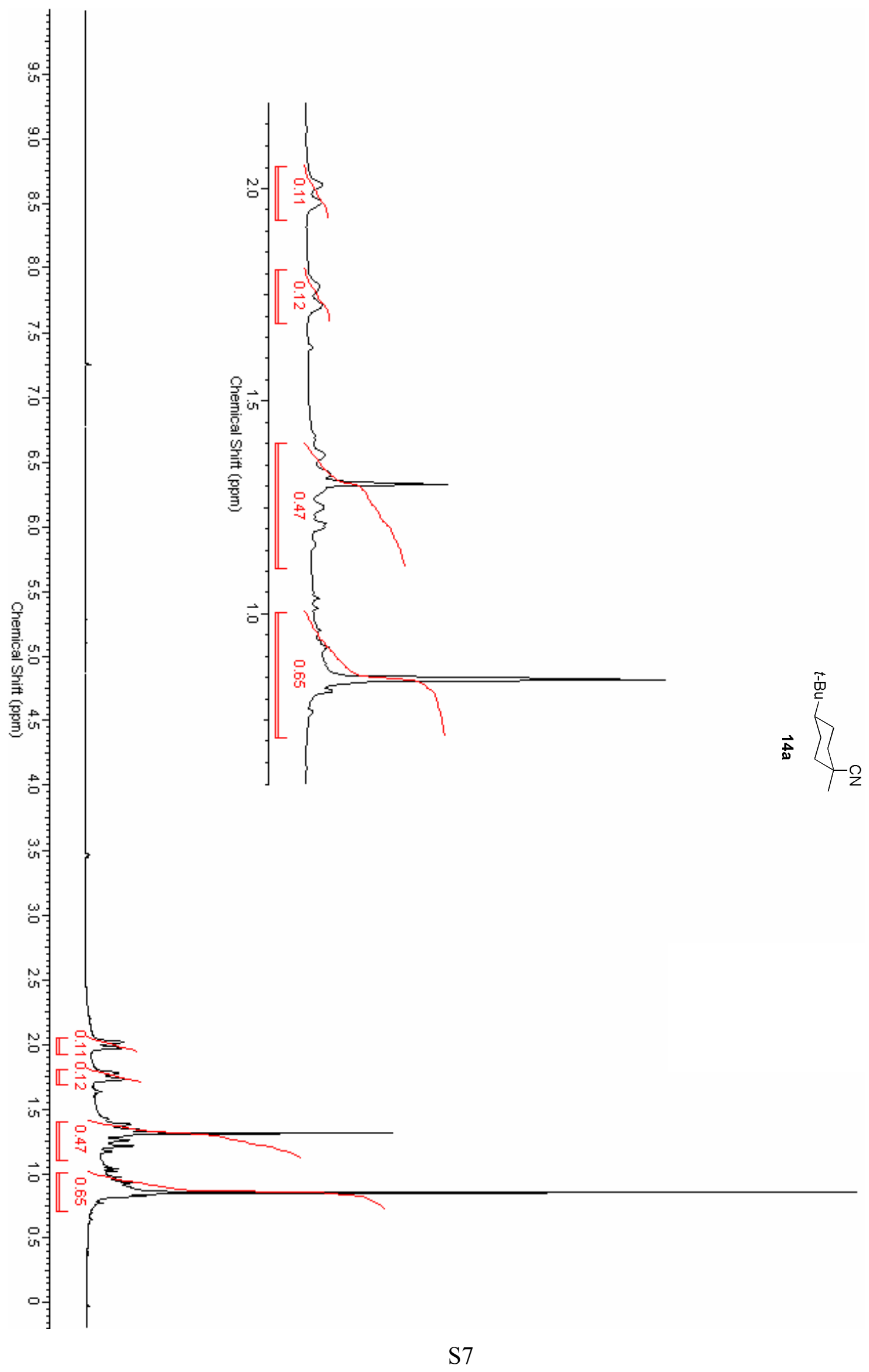




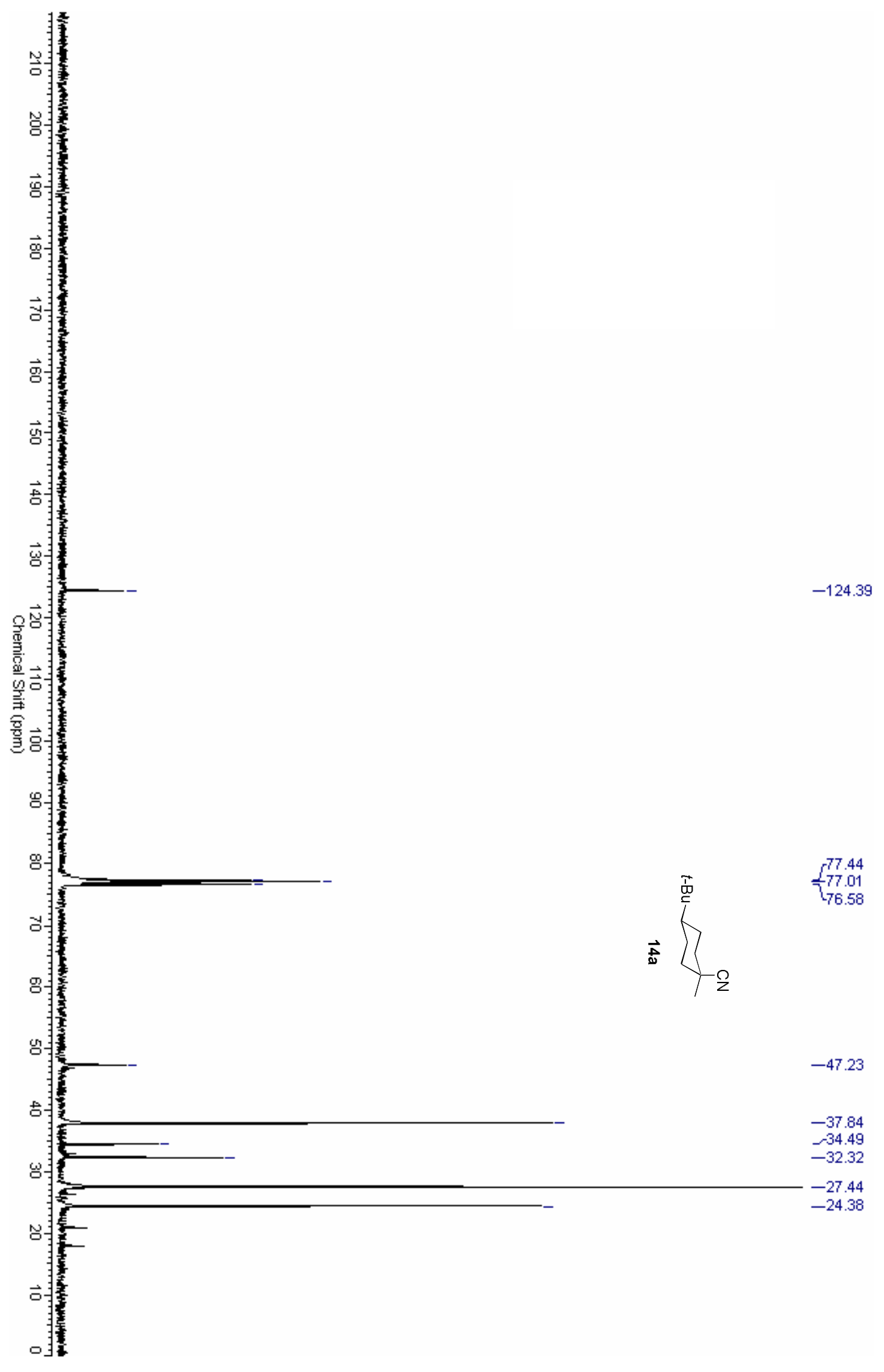




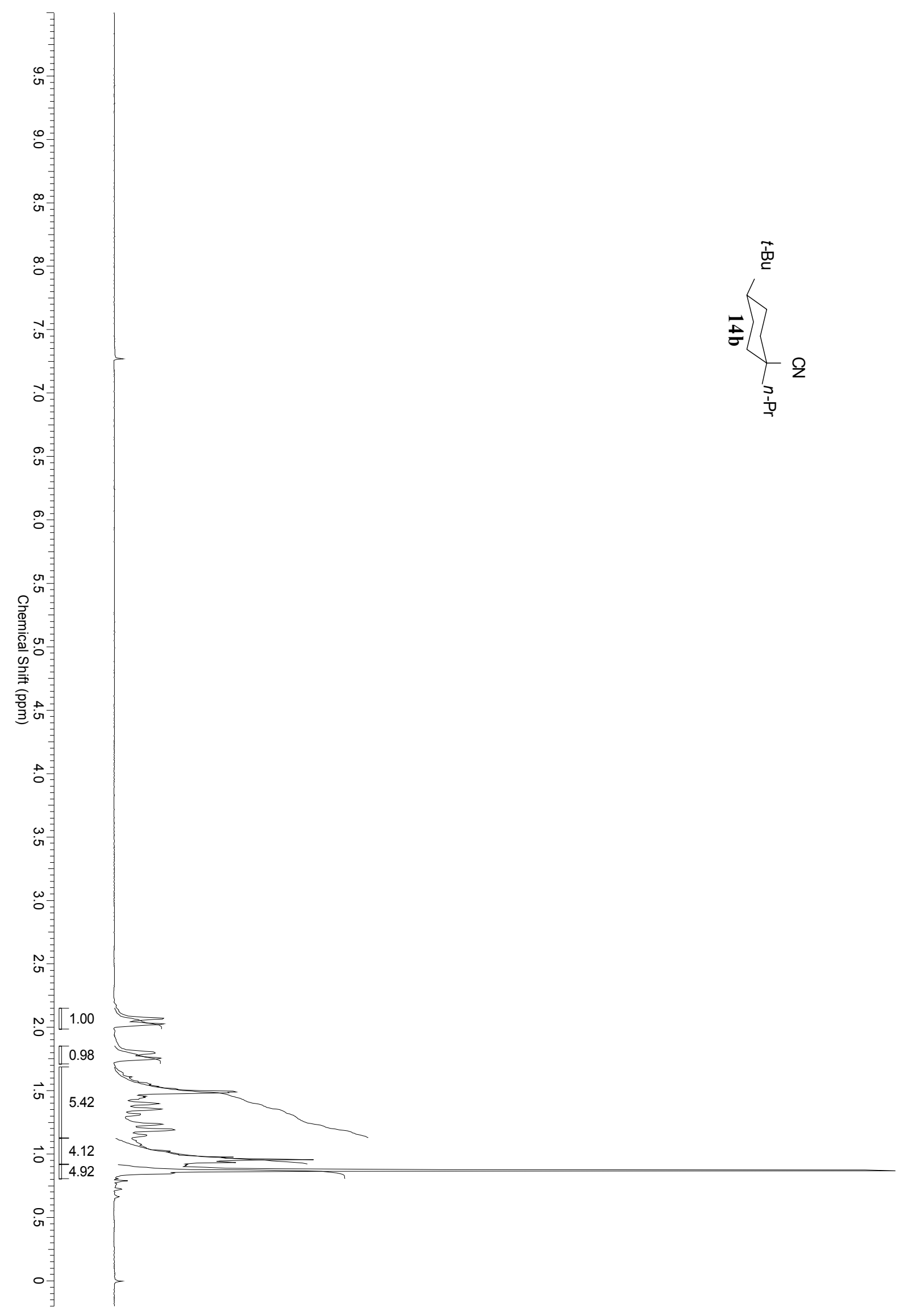




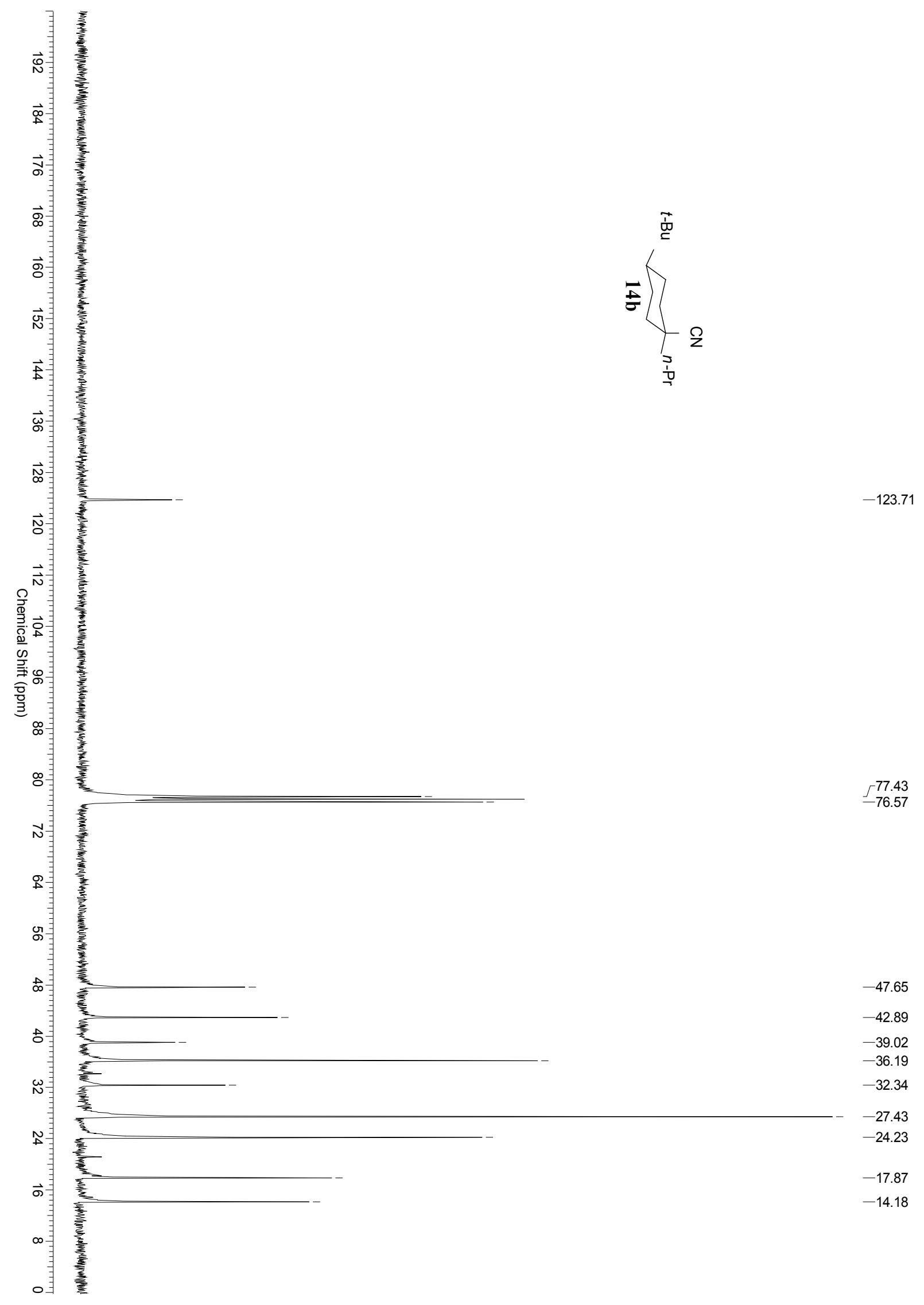




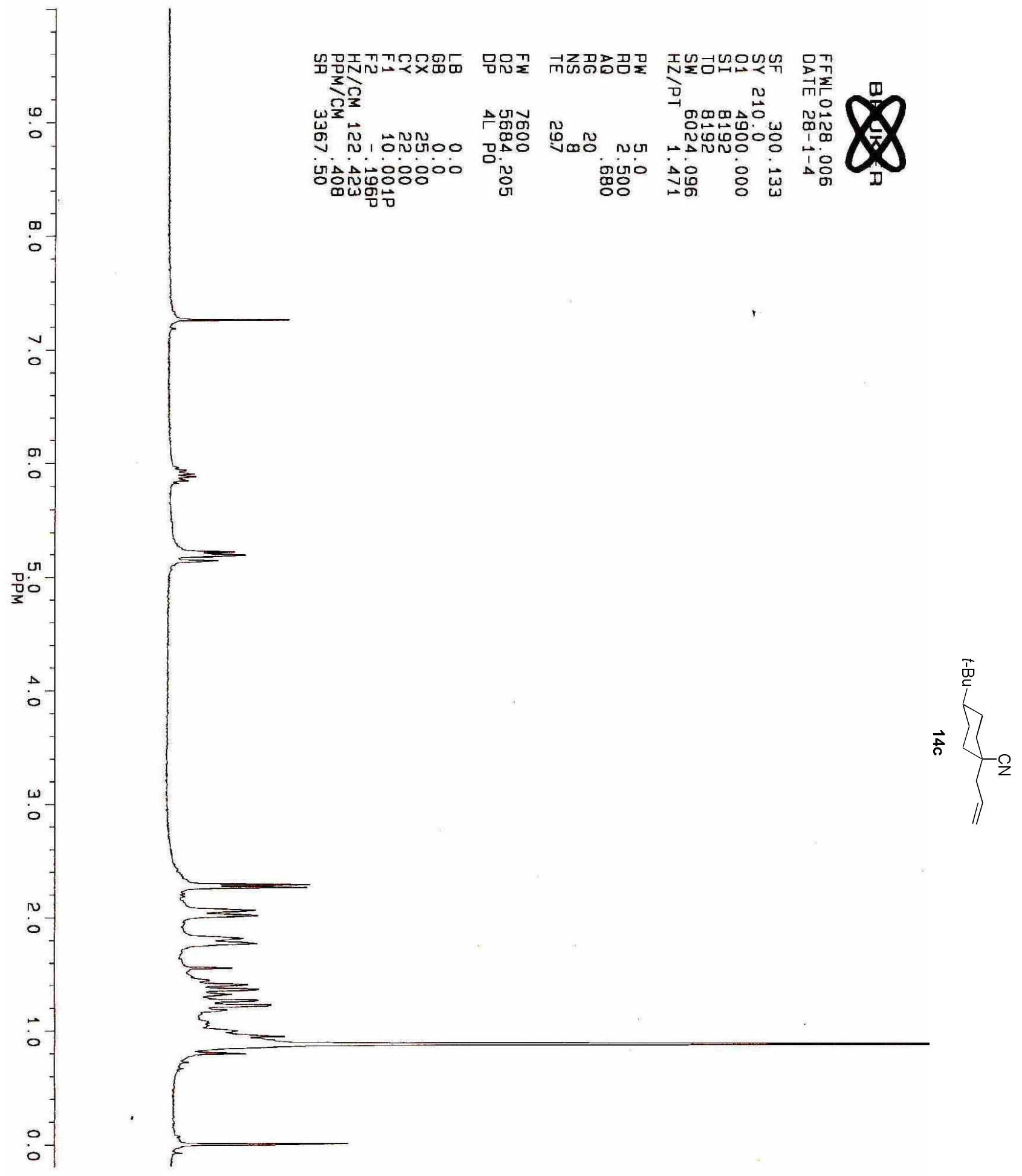




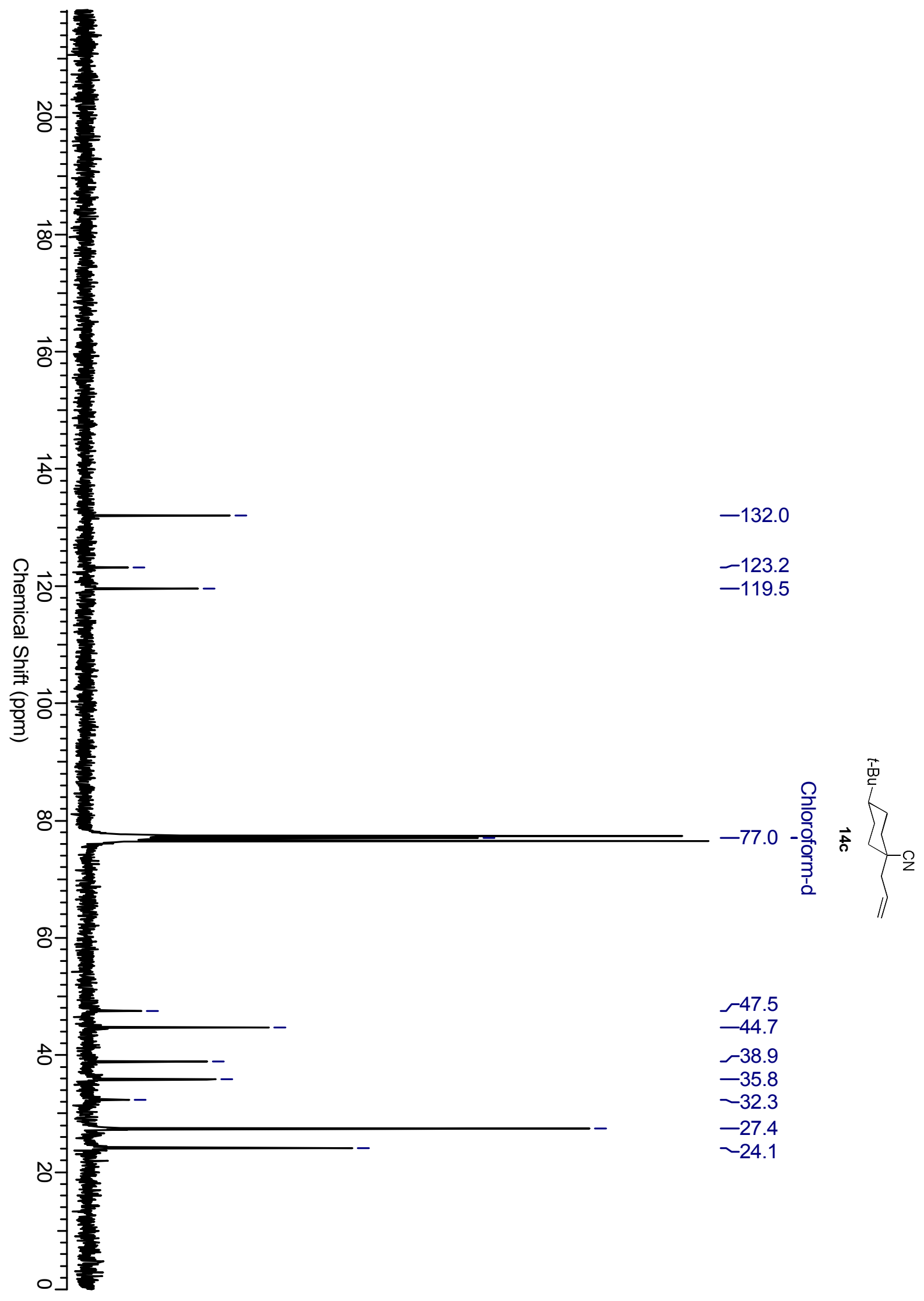




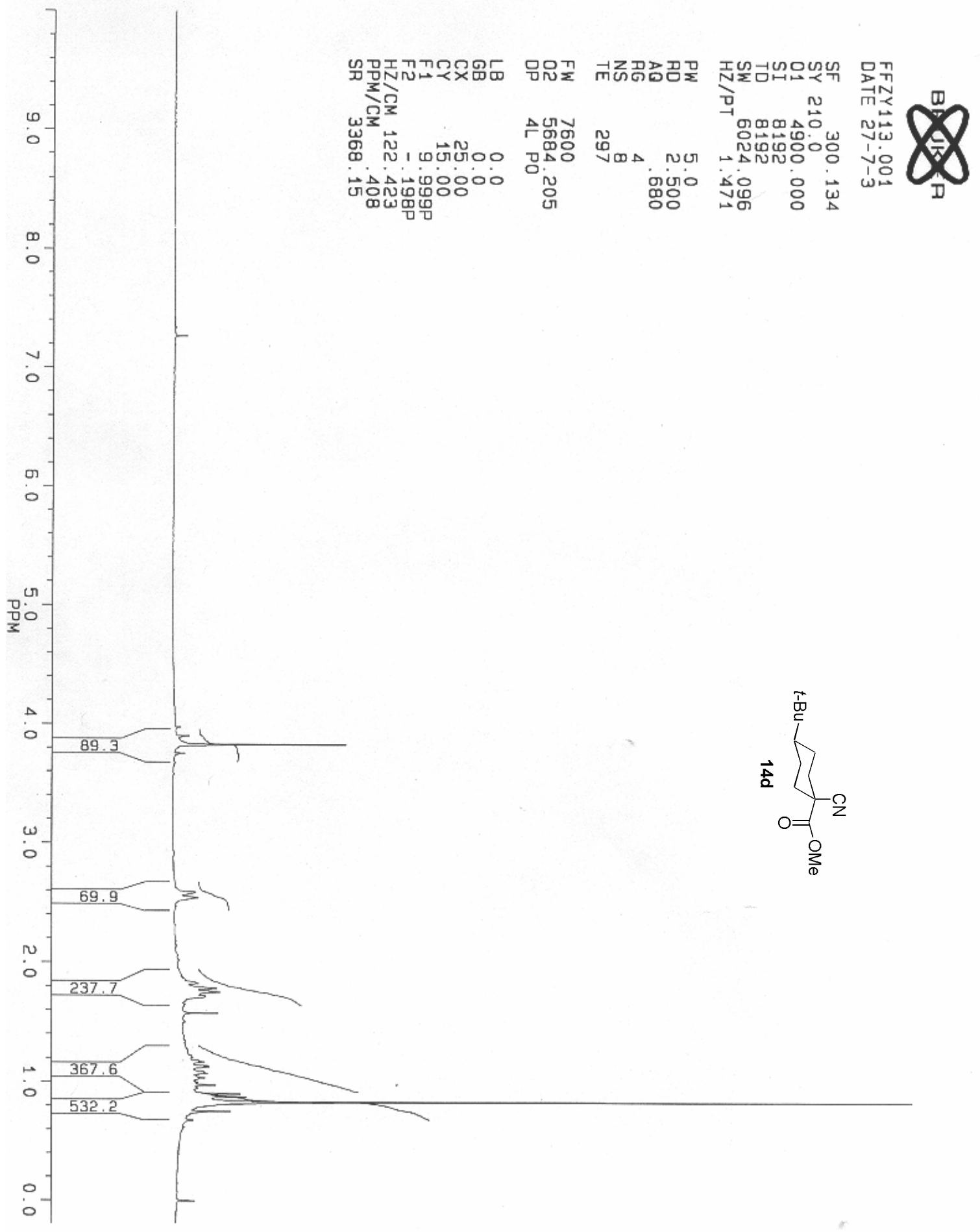




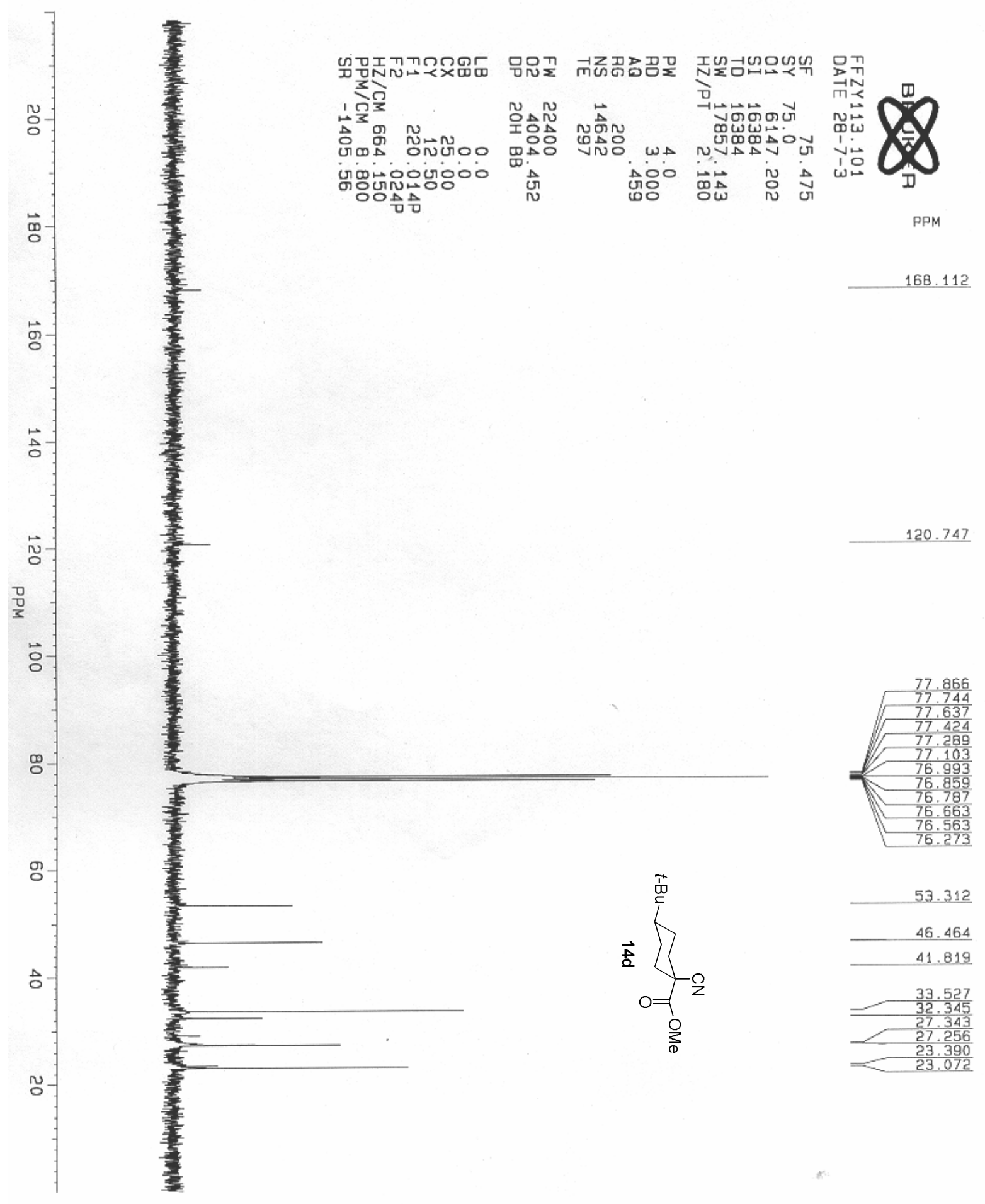




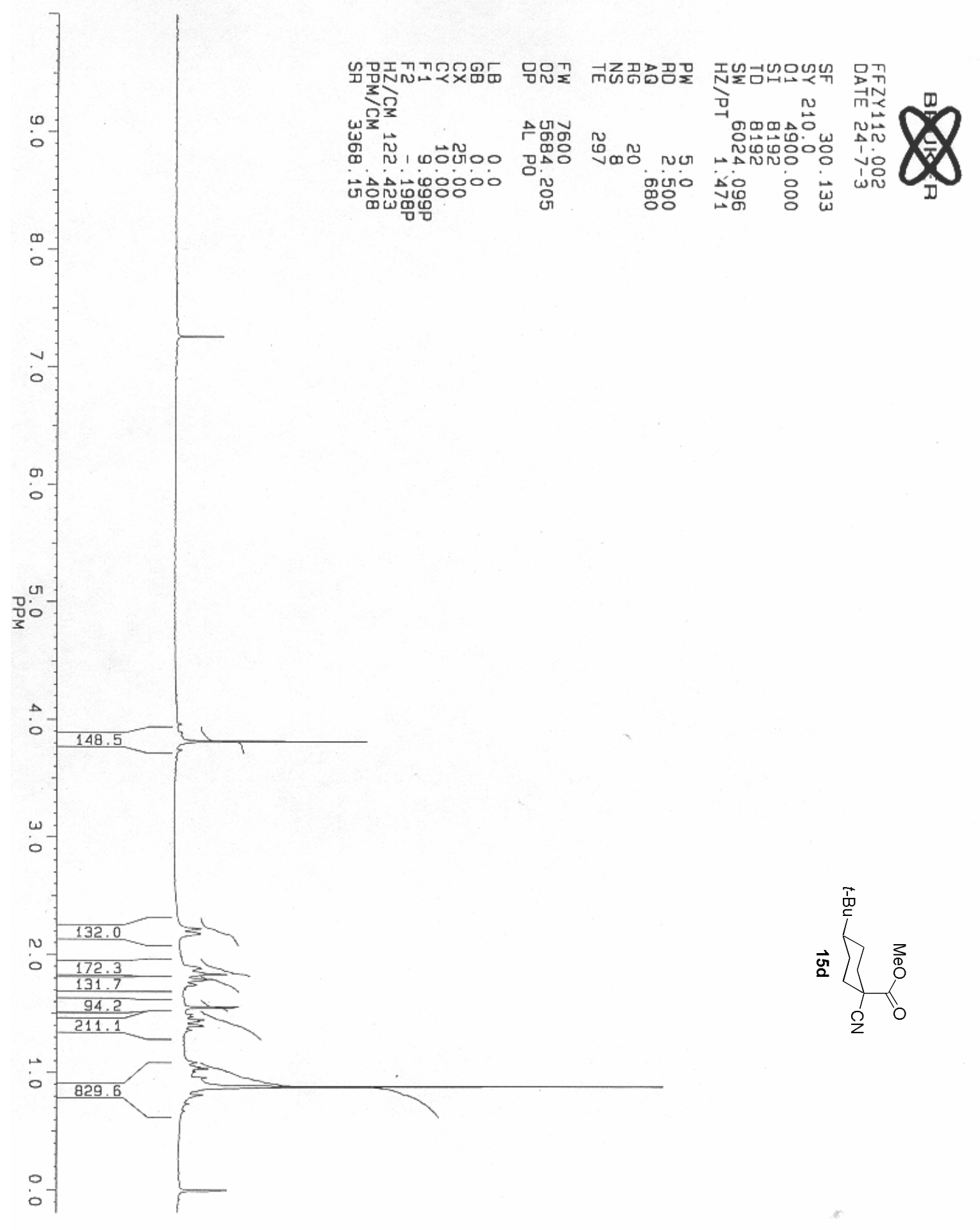




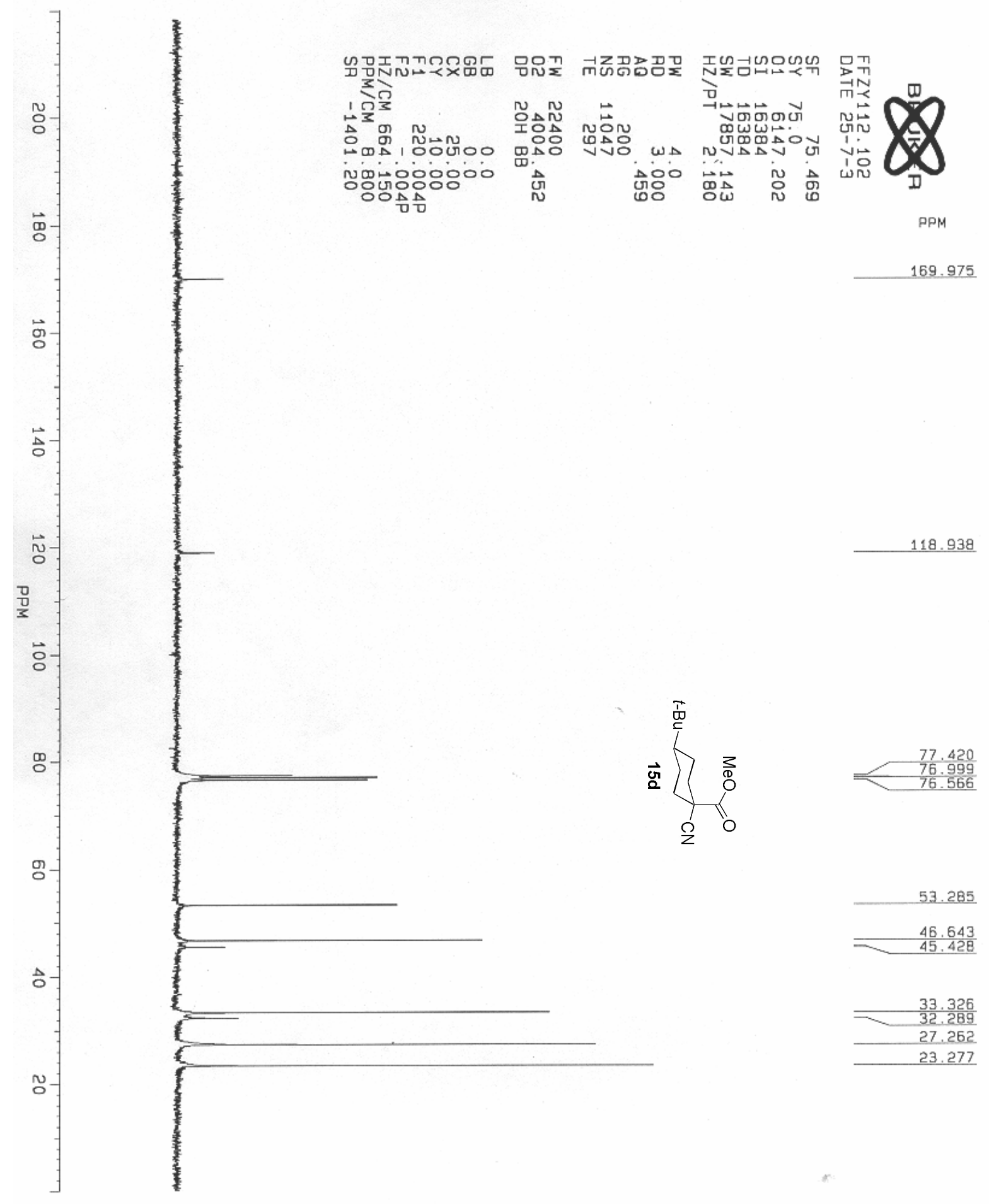




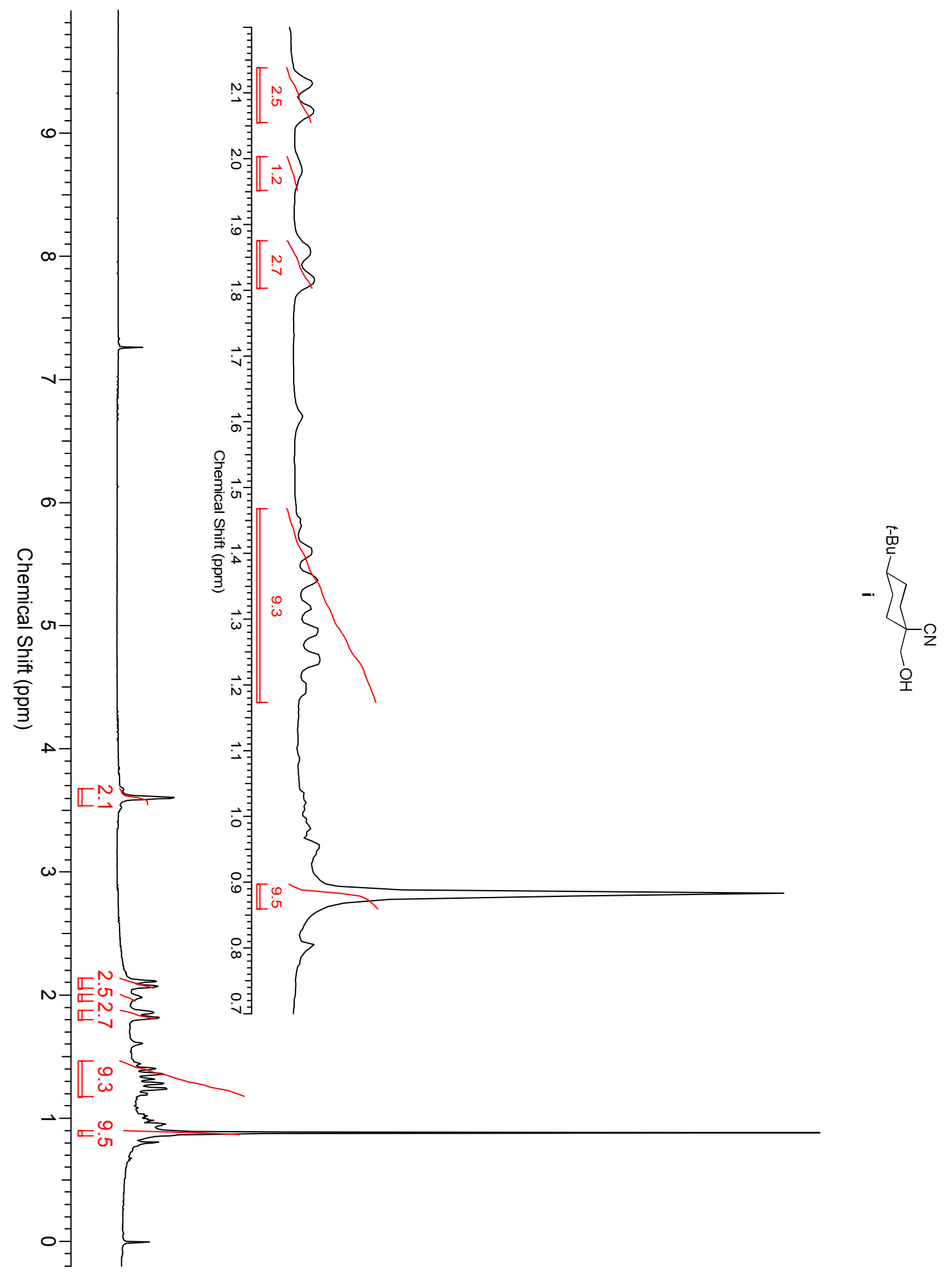




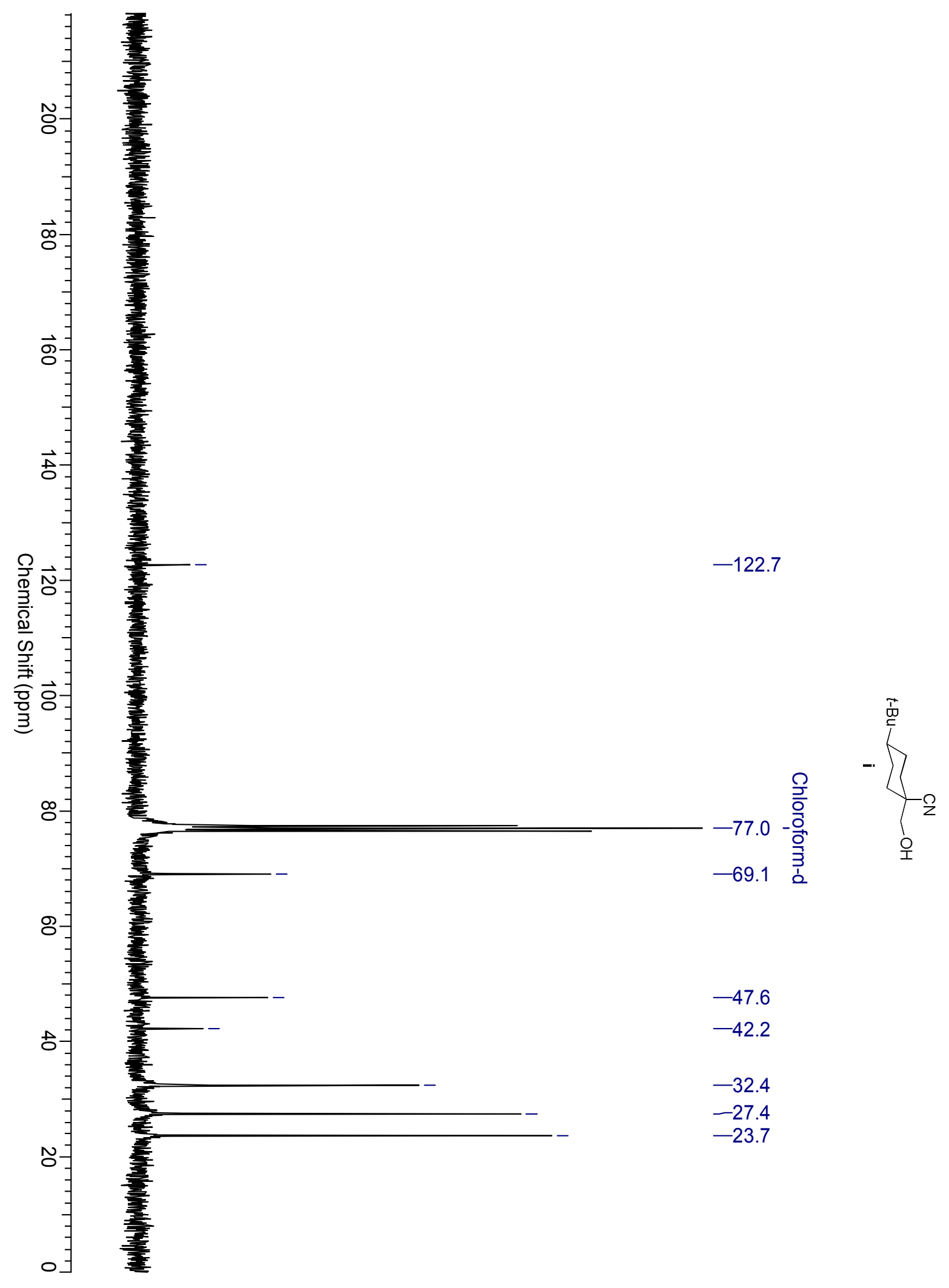




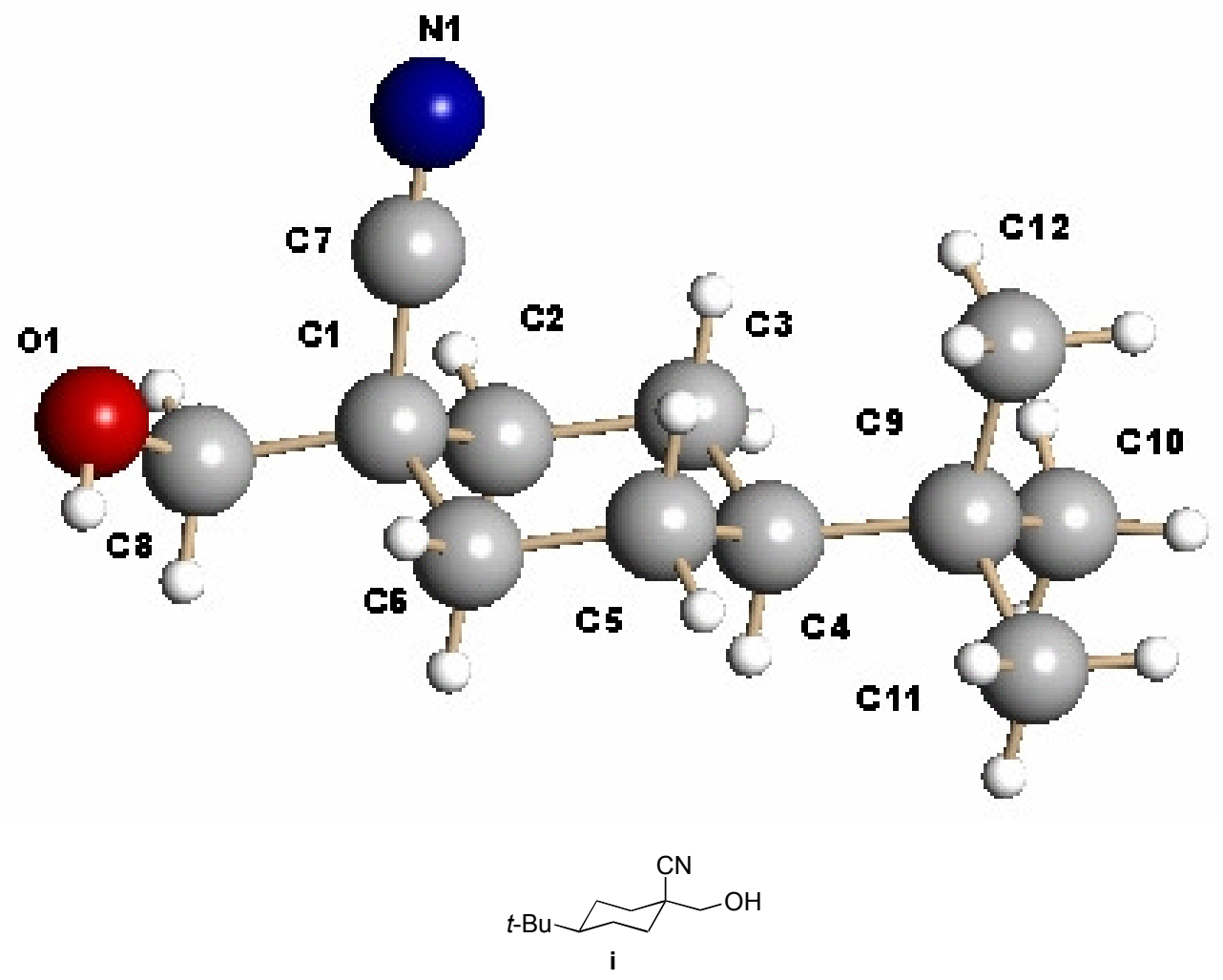




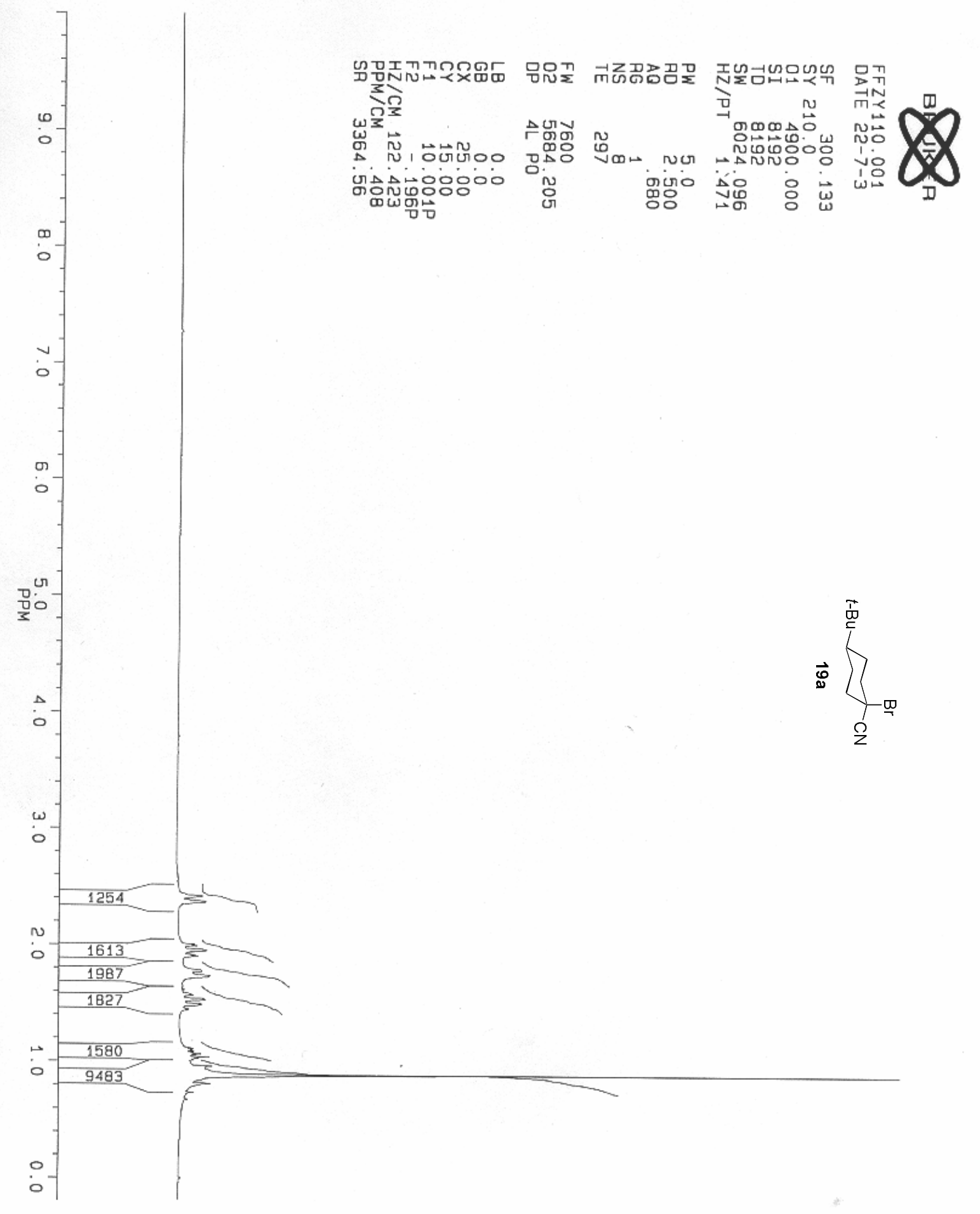




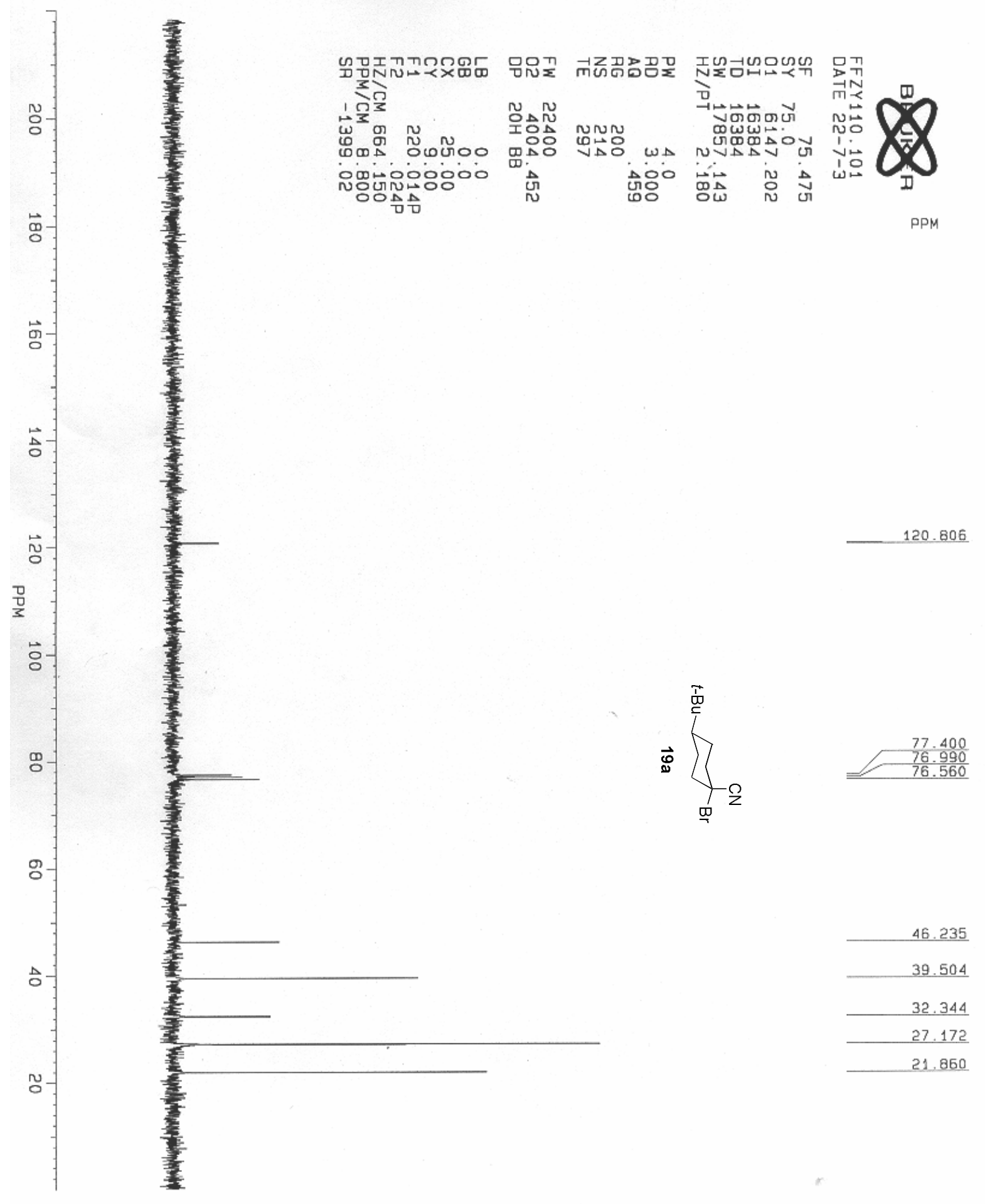




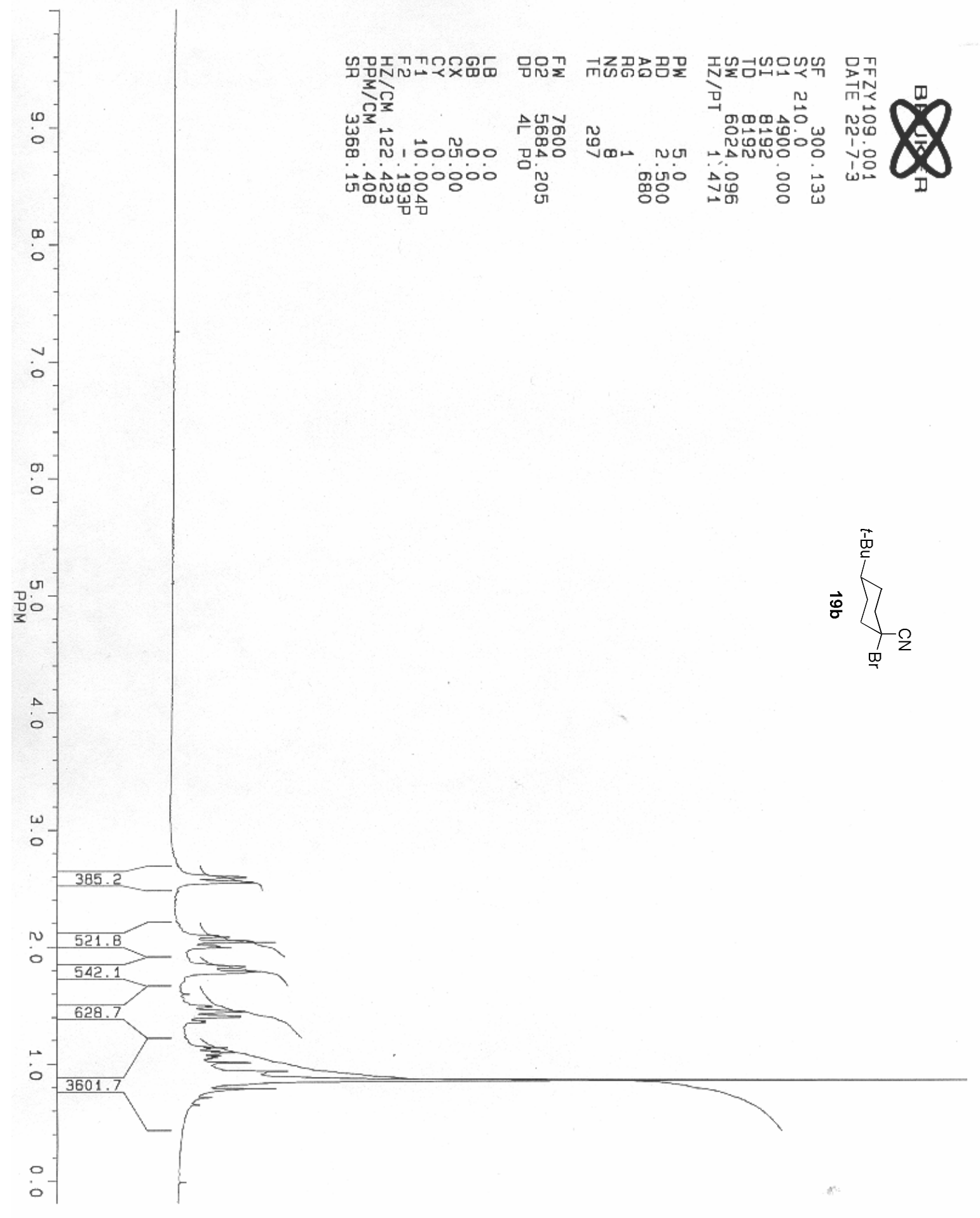




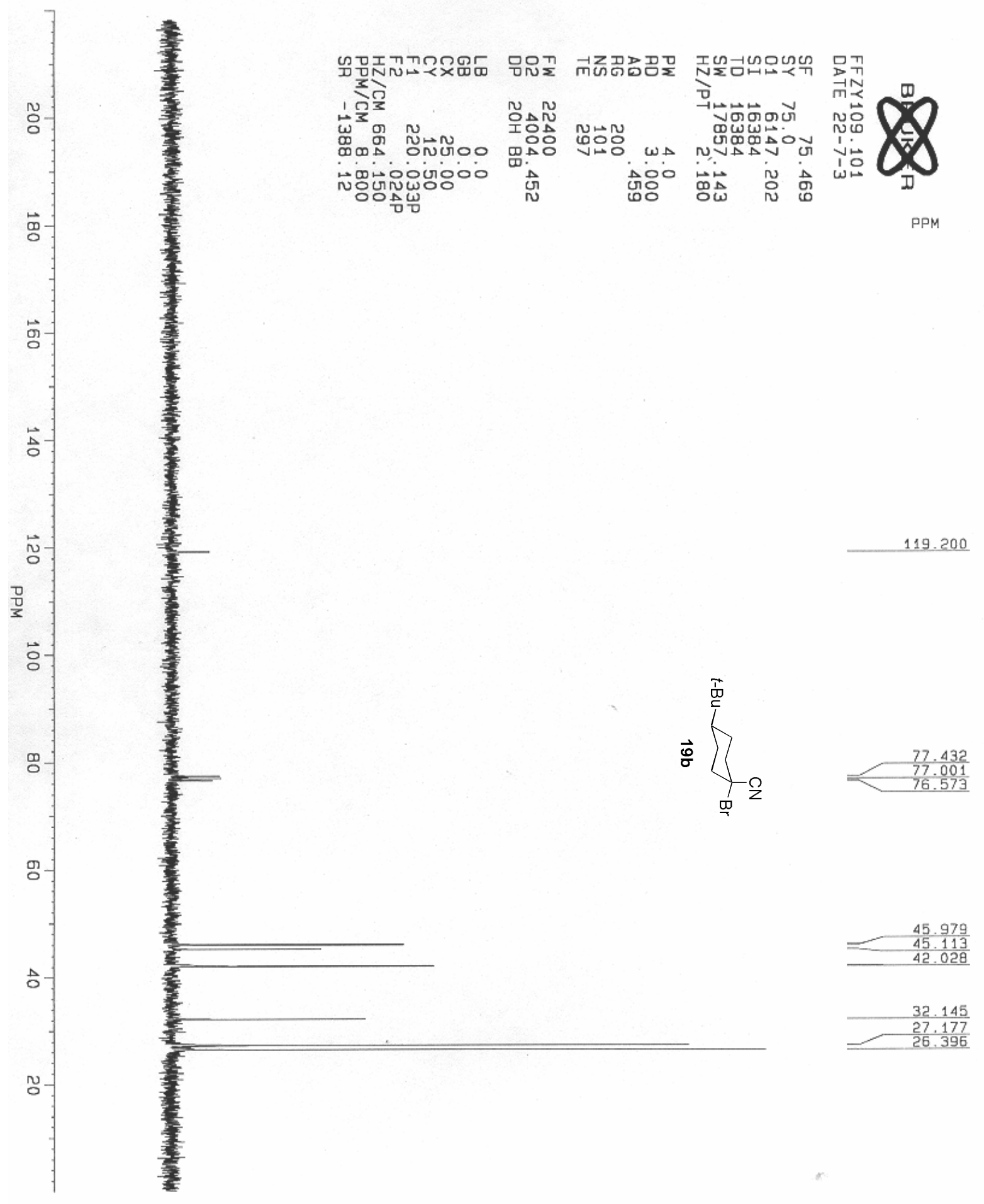




\section{$\underline{\text { References }}$}

1 The supplementary crystallographic data for i, CCDC\# 259789, can be obtained free of charge via www.ccdc.cam.ac.uk/conts/retrieving.html or from the Cambridge Crystallographic Data Center, 12 Union Road, Cambridge CB2 1EZ, UK (fax +44 1223 336033; ordeposit@ccdc.cam.ac.uk.).

2

(a) House, H. O.; Bare, T. M. J. Org. Chem. 1968, 33, 943. (b) Bailey, W.; Cioffi, A. Magn. Reson. Chem. 1987, 25, 181.

3 House, H. O.; Lubinkowski, J.; Good, J. J. J. Org. Chem. 1975, 40, 86.

$4 \quad$ For general experimental procedures, see: Fleming, F. F.; Hussain, Z.; Weaver, D.; Norman, R. E. J. Org. Chem. 1997, 62, 1305.

$5 \quad$ Prepared from the corresponding ketone by cycloaddition with $p$-toluenesulphonylmethyl isocyanide (TosMIC) ${ }^{\mathrm{a}-\mathrm{b}}$ to give material identical to that previously characterized. ${ }^{\mathrm{c}}$ (a) Gerlach, U.; Haubenreich, T.; Hünig, S.; Keita, Y. Chem. Ber. 1993, 126, 1205. (b) Gerlach, U.; Hünig, S. Tetrahedron Lett. 1987, 28, 5805. (c) Okimoto, M.; Chiba, T. J. Org. Chem. 1990, 55, 1070.

6 Determined by integration of the ${ }^{1} \mathrm{H}$ NMR $(500 \mathrm{MHz})$ signals for the respective $t$-butyl groups. 